\title{
The UN and the Universal Language of Children's Rights
}

\author{
Hon. Landon Pearson, O.C.
}

The United Nations was founded in 1945 so that the world could be restrained from destroying itself through armed conflict as it nearly had during World War I and World War II. The preamble to the UN Charter reads "We the peoples of the United Nations determined to save succeeding generations from the scourge of war... and to reaffirm faith in fundamental human rights and the dignity and worth of every human person...have resolved to continue our efforts to accomplish these aims." This powerful statement affirmed that all human rights are universal and worth protecting including the rights of children. Three years later, on Dec. 10, 1948, the indomitable Eleanor Roosevelt, who had inspired the idea of a Declaration and chaired the drafting committee that drew it up was able to present the Universal Declaration of Human Rights to the UN General Assembly of the UN that was meeting at the Palais de Chaillot in Paris, France where it was adopted if not unanimously at least without registered dissent. In consequence the Declaration is considered to be the common standard of achievement for all peoples and all nations. A number of treaties and conventions have subsequently been negotiated under the auspices of the UN to put flesh on this Declaration including the Declaration on the Rights of the Child which was adopted at the UN on Nov. 20, 1959. It was this Declaration that framed the work of the national commissions called for by the UN resolution that established 1979 as the International Year of the Child (IYC). I was vice-chair of Canada's Commission and as we developed a national agenda for action entitled "For Canada's Children" it became clear that a declaration was not a strong enough instrument to bring about the changes in government and civil society that we all agreed were necessary to make a positive difference in the lives of children. Other national commissions had come to similar conclusions and so the UN resolved to transform the Declaration on Children's Rights into a convention that would have the force of international law.

Canada was very active at the UN in those days. A Canadian, John Humphrey, was the principal drafter of the Human Rights Declaration and so Canada was invited to serve on the working group that was tasked with transforming the UN Declaration on the Rights of the Child into a binding treaty that would make all the countries that ratified it accountable to the international community. Perhaps because it is about children the preparation of the Convention on the Rights of the Child (CRC) was unusually open to civil society engagement and some of us who were working with non- 
governmental organizations (NGOs) at the time managed to have some real input into the final document. The inclusion of children of Indigenous origin in article 30 and the right to play in article 31 are attributed to Canadian influence. After ten years of work the CRC was ready and then, on November 9, 1989, the Berlin Wall came down essentially bringing to an end the Cold War and the so-called East-West split that had served to separate human rights into two baskets: civil and political rights were heavily promoted by the West and economic, social and cultural rights by the East which meant mostly the Soviet Union and the Eastern Bloc. Since the CRC had incorporated both it had to wait until tensions eased between the two blocs before it could be submitted to the General Assembly of the UN. The Wall fell and eleven days later, on November 20, 1989, it was unanimously adopted. By the time of the World Summit on Children, which took place in New York on September 29-30 1990, enough countries had not only signed but also ratified the CRC so it had come into force. Now 196 member countries of the UN have ratified it. The only Member that hasn't is the United States of America although President Bill Clinton did sign.

With the CRC now firmly in place there was steady progress over the next twelve years towards a broader recognition of children's rights and what to do to implement them until the collapse of the twin towers in New York on September 9, 2001 radically shifted national priorities. This progress was made possible thanks to the language that was being crafted at UN conference after UN conference during the 1990s. For those of us who were watching, it was a very exciting time and some of us, luckily, were able to be actively engaged. It was a privilege for me both before and after I became a Senator to sit with fellow Canadians at negotiating tables as we worked our way through some of the trickier language. The blueprint for all our efforts was the CRC but it was clear that many of its articles still needed to be unpacked so as to make their intentions clear and actionable. The World Summit on Children, at which Canada played a really useful role, was an important first step in this process. The idea for the Summit came from James Grant who was then the director of Unicef. He easily persuaded Canada to join five other "initiating” countries (Sweden, Mali, Egypt, Pakistan and Mexico) to work on the outcome document and encourage leaders from as many countries as possible to come and make the Summit a significant world event. Prime Minister Brian Mulroney took up this challenge with enthusiasm and co-chaired the Summit itself with skill and grace. The intent of the Summit was to inject substance into the words of the CRC emerging with a plan of action that the 159 leaders (Heads of State, Prime Ministers and senior officials) who were present could sign on to and implement when they returned to their home countries. I was invited to 
join our delegation at the Summit as a representative of civil society and to bring with me a young girl who had been chosen by her peers to represent them. Mr. Mulroney was exceptionally open to young people and their ideas making it possible for the organization I then chaired, the Canadian Council for Children and Youth, to bring together a group of children under the age of 18 from all over the country to develop their own declaration for the Summit He accepted it from them in his office on Parliament Hill and took it with him to New York.

Mr. Mulroney made good on his commitment as soon as he returned to Ottawa. He designated then Minister of Health and Welfare, Benoît Bouchard, as Minister for Children mandating him to establish a children's bureau within his ministry which was tasked with developing, in cooperation with the provinces and territories, a Canadian Plan of Action to implement the World Summit goals. This plan, called "Brighter Futures," was launched in 1992. At the same time, funds were made available for a number of specific projects related to children. CIDA was asked to develop programmes for children in especially difficult circumstances around the world and given a generous budget for the task. The newly formed NGO I was now chairing, the Canadian Coalition for the Rights of the Child (CCRC), was invited to work with CIDA to choose innovative projects and then evaluate their success. The CCRC was also funded to bring children from across the country to Ottawa on December $13^{\text {th }}$, 1991 so that, in the great Hall of Parliament sparkling with Christmas lights, they could witness the signature that Prime Minister Mulroney was finally able to affix to the instrument of Canada's ratification of the Convention on the Rights of the Child thanks to the agreement of the provinces and territories from which the children had come.

Brian Mulroney resigned as Prime Minister in June 1993 and Canadian children lost a champion but internationally, a spate of conferences sponsored by the UN continued to explore and articulate issues important for children's rights and Canada was active at all of them. The first was the Earth Summit (the UN conference on the Environment and Development) held in Rio in June 1992. A Canadian, Morris Strong, was the Secretary-General of the Conference and two young Canadians were able to speak to it one of whom had been selected by a group of young people the CCRC had brought together at Econiche in the Gatineau to explore environmental issues. Agenda 21, the outcome document from the Rio Conference remains hugely relevant today, and not just for children.

The next UN sponsored conference was held a year later in Vienna. In June 1993, world leaders gathered there to discuss human rights, hopeful that with the end of the Cold War, human 
rights would be able to gain new traction in state and inter-state actions. The agreed upon definition that came out of that conference applies to children as well as to all other members of the human family and reads that, "all human rights are universal, indivisible, interdependent and interrelated." So now the concept of the relational nature of human rights was firmly embedded in the lexicon. Later that year, a UN sponsored group of experts gathered in France to establish what came to be known as the Paris Principles. These set out the rules for Independent Human Rights Institutions, rules that are respected not only by human rights defenders worldwide but also by most child advocates or children's commissioners in the countries in which they exist.

In June 1994 Cairo attracted a large number of national representatives to the UN Conference on Population and Development (1994) where 20,000 delegates were able to agree on four main goals, all of which are vital for the promotion of children's rights: universal education; reduction of infant and child mortality; reduction of maternal mortality; and access to reproductive and sexual health services. The Cairo Conference coincided with the UN designated International Year of the Family so in July of that year, I attended a well-funded regional conference in Victoria, B.C. entitled "Stronger Children, Stronger Families"; it was notable for the presence of many young people and for efforts to reverse the usual way in which people perceive power in families. Also in 1994, Canada submitted its first report on implementation of the CRC to the UN Committee on the Rights of the Child in Geneva in accordance with CRC Article 42.

Later that year, in September 1994, I was appointed to the Senate of Canada and asked by Prime Minister Jean Chrétien to speak up for children. I did not attend the World Summit on Social Development in Copenhagen the following March which was aimed at creating a people-centred framework for social development all over the world, but in September of 1995, I joined the Canadian Parliamentary delegation to the Fourth World Conference on Women in Beijing. I was asked to focus on the girl child as this was the first time at an international conference on women that girls were to be considered separately for inclusion in the Platform for Action. Beijing was a remarkable experience. In order to talk with the many girls who had come with civil society delegates so that we could collect their views, we had to be driven 40 kilometres outside of Beijing to where the NGOs were housed. However, thanks to the efforts of Unicef, some of these same girls were allowed to speak to the full conference and ensure that their section of the Beijing Platform for Action would reflect their ideas and opinions. Section L is a powerful and comprehensive call to eliminate all forms of discrimination against the girl child including negative cultural attitudes and 
practices. Section L also calls for the empowerment of the girl child through educating her about her rights and enabling her to have a voice. Reading that section today is quite inspiring. Much remains to be done of course but the yardsticks are clearly staked and there can be no going back. Unicef, to its credit, also managed to organize a full day during the official conference devoted to the girl child and it was there, sitting beside Lisbeth Palme, the widow of Olaf Palme, that I first learned that a First World Congress Against the Commercial Sexual Exploitation of Children (CSEC) was scheduled to take place in Stockholm the following September. As the newly appointed (1996) Advisor on Children's Rights to Lloyd Axworthy, Canada's Minister of Foreign Affairs, I was able to co-lead our Canadian delegation and persuade Mr. Axworthy to attend on the final day.

The 1996 Stockholm Congress on CSEC made a major contribution to children's rights language. We had an excellent delegation that included a young woman named Cherry Kingsley whom I first met in 1994 at the Stronger Children, Stronger Families Conference. Cherry was the only experiential young person at the CSEC Congress and what she had to say, when she was given the opportunity to speak, made everyone sit up. In those days the sexual exploitation of children and young people was a reality that few wanted to talk about and this Congress made language about it possible so that it could be seen for what it was, an unacceptable infringement of a child's right to be free from the kind of abuse that was inflicted solely for adult gratification, a crime against that child's humanity. When I returned to Canada, Mr. Axworthy asked me to follow-up on the commitments that he, on behalf of Canada, had undertaken on the final day of the Congress to address the issue. What I did was set up an ad hoc working committee of the Senate to gather as many stakeholders as possible to plot the way forward. In March 1998, with the help of the Government of Canada and Unicef, Cherry Kingsley and I co-chaired a Summit of sexually exploited young people from the Americas in Victoria B.C. After several days of constructive interaction in a variety of modes, the young people insisted on changing the language with which they had typically been characterized. They were not "juvenile prostitutes" but "young people exploited in the sex trade." This language has changed the way they are perceived and is the term that is now internationally accepted. I attended a second World Congress on CSEC with Cherry in Yokohama in Dec 2001 where she spoke again along with other experiential young people who raised, among other abuses they had encountered, new risks associated with the growth of social media and the Internet.

In the meantime, I had attended two other language changing events, one in Oslo on child labour in 1997 and another in Winnipeg in 2000 on war-affected children where, under the baton of 
Lloyd Axworthy, we negotiated language about child soldiers with a certain degree of intensity. The Winnipeg Conference was, in part, an update of Graça Machel's 1996 report to the UN on the impact of armed conflict on children, a report that had opened our eyes to the suffering of children who were being used as instruments of war. It was also a continuation of Mr. Axworthy's work to ban the use of landmines. The Ottawa Process, as it became known, resulted in the Landmines Treaty which was signed in 1997 and became binding law with enough ratifications in 1999. Banning landmines was a passionate concern for Princess Diana who was appalled by the injuries and deaths inflicted by them on children and I, too, remember being horrified by seeing a pile of actual landmines on the table in the Commonwealth Room in Parliament and recognizing how attractive they might seem for little children to play with so I applauded when Jody Williams, and the International Campaign to Ban Landmines, received the 1997 Nobel Peace Prize for their work. However, it is Lloyd Axworthy who must be given the credit for shepherding the Landmines Treaty through to its final stages.

Many young people were now becoming more active on child rights issues which was encouraging progress since the time of the World Summit when children were present to be seen but only heard when they were singing in a choir. By the time we approached the UN General Assembly Special Session on Children that had been scheduled to take place in New York during the very week the twin towers collapsed, children and young people had a great deal to say and were being allowed to say it.

The Special Session on Children (2002) was intended to mark progress made since the World Summit on Children that had taken place a dozen years earlier. Once again, Canada was one of six initiating countries and Prime Minister Jean Chrétien designated me as his personal representative, his "Sherpa" so to speak, and we agreed that our priorities should be child and youth participation, cooperation with the Americas, and children with disabilities. This enabled me to attend all the preparatory sessions from Barbados to Jamaica to New York and to bring two young people with me on our delegation to each meeting with their expenses picked up by the Government of Canada. At the Session itself, postponed for a year from 9/11, we had six young delegates including a First Nations youth from Alberta, an Inuit young man from Nunavut and a Métis girl from Newfoundland, all of whom, having attended at least one preparatory committee meeting, were able to speak out with authenticity. The other three were girls from British Columbia, Saskatchewan and Montreal, wonderful representatives of the diversity of our nation. As a country we were proud of the leadership we were showing in engaging youth in a meaningful way. At the first preparatory meeting 
in 1998, there were only two or three other countries that included children on their delegations but, in the end, 132 countries chose to bring children and youth to the Special Session and they made a remarkable difference to the tone of the event.

The outcome document of the Special Session was entitled "A World Fit For Children.” It noted all the advances made since the World Summit including clarifications of child rights language and articulated an updated list of priorities for action. Each member state of the UN committed to developing its own Plan of Action and I was charged with directing the process in Canada with the help of knowledgeable officials and government funding. We consulted widely across the country, including with children and young people, and our own young delegates joined with a number of others to be a sounding board. In the spring 2004 we launched “A Canada Fit for Children: Canada's National Plan of Action" in the Senate foyer. This document was then adopted by Cabinet and I was asked to take it to New York to submit it to Unicef as proof that Canada was planning to live up to the commitments we had made at the Special Session. We were one of the first countries to do so. I was joined in New York by a representative of the Government of Québec carrying his province's own action plan because Québec is justifiably proud of its substantive support for children which it continues until today.

In many ways this trip signalled that the window on children's rights that had been so open during the previous twelve years was beginning to close. There was still the UN Study on Violence against Children to come. The North American regional consultation for that study organized by Unicef Canada was held in Toronto in June 2005 to which I spoke on behalf of the Canadian Government since I was still Advisor on Children's Rights. A considerable effort had been made to collect youth voices and the large number of young people there were very eloquent about their own experiences and able to add conviction to Dr. Sergio Pinheiro's statement when he presented his report to the UN in 2006 noting that, "no violence against children is acceptable and all violence against children is preventable."

The language window is not entirely closed. There have been three Optional Protocols to the $\mathrm{CRC}$, two of which are intended to clarify language related to children in armed conflict as well as to sexually exploited children and were adopted by the General Assembly. Both have been ratified by the US as well as by Canada and came into force in May 2002. The third, a complaints mechanism intended to be available when domestic law fails to provide remedies for abuse, remains open. There have also been numerous regional meetings on a variety of children's issues. However. the main 
source nowadays of agreed upon language is the UN Committee on the Rights of the Child which has issued 24 General Comments designed to guide State Parties to the Convention, all 196 of them, in their understanding of the articles of the CRC. Under construction at the moment is a twenty-fifth comment, this one on the rights of children in the digital environment which should be particularly helpful as we come to terms with the impact on children's rights of the current pandemic and of the explosion of social media.

We all recognize nowadays that words matter, that language matters and that the ways in which we talk about children and other minority groups shape the ways in which we relate to them. Slogans to address discrimination can be effective for a time but they are usually not sustainable and sometimes they can be downright harmful. What is really necessary is the careful crafting of internationally agreed upon language so that countries, societies and individuals can be aware of how they should behave and what it means to respect, protect and fulfill the rights of all children everywhere. Although the UN uses six official languages, we know that human beings speak many more, almost too many to count. We also know that some concepts are difficult to translate from one language into another, but this does not take away the universality of children's rights language. The abuse of children is unacceptable in any language and children have the right to be heard in whatever language they choose. Before the $\mathrm{CRC}$, children were to be seen but not heard and we neither listened to them nor did we understand the degree to which their rights were being abused. We felt sorry for them if they were being overworked and horrified if they were being trafficked, but our response tended to be one that was charity based rather than rights based. Children's needs for protection and provision are relatively easy to understand and the charitable response is fairly straightforward and sometimes it is adequate. But granting children civil and political rights, for example, demands that we think about them in a different way. However, after the adoption of the $\mathrm{CRC}$ and twelve years of conferencing, we now have the language necessary to help us understand what it means to listen to children and listen to them we must because, as the two young girls who stood at the podium at the UN Special Session representing all the others who were there declared, "a world fit for children is a world fit for everyone" and "we are not the problem, we are the solution."

This issue of the CJCR embodies much of the universal language of children's rights that I have been describing. It focuses on children's rights in education. Certain new issues have come to the forefront since the World Summit 30 years ago and the Special Session in 2002, notably the challenge for children's rights of the digital universe and the increasing threats associated with 
climate change. Yet in Rio, the appropriate language was already emerging. This is what was said then: "An empowering education is one that builds the human resources we need to be productive, to continue to learn, to solve problems, to be creative and to live together with peace and harmony." With the energizing of the young there is still hope!

\section{Landon Pearson}

Nov. 1, 2020

*For those who want to know more all Declarations, Conventions, and outcome documents from UN sponsored Conferences cited here are available on the UN Website. 